\title{
Solving an incomplete puzzle: risk factors of low back pain during pregnancy
}

\author{
Serap Fırtına Tuncer ${ }^{1}$, Hasan Aykut Tuncer ${ }^{2}$ (D) \\ ${ }^{1}$ Department of Obstetrics and Gynaecology, University of Health Sciences Antalya Training and Research Hospital, Antalya \\ Eğitim ve Araştırma Hastanesi, Antalya, Turkey \\ ${ }^{2}$ Department of Obstetrics and Gynecology, Akdeniz University School of Medicine, Akdeniz Üniversitesi Tıp Fakültesi Hastanesi, \\ Kadın Hastalıkları ve Doğum Anabilim Dalı, Pınarbaşı Mahallesi, Antalya, Turkey
}

\begin{abstract}
Objectives: Low back pain during pregnancy is a common disorder with an obscure etiopathogenesis. This study sought to investigate the association of low back pain by assessing various epidemiologic and clinical risk factors including weight changes, the presence of striae gravidarum, and intraperitoneal adhesions.

Material and methods: A total of 250 pregnant women between 37 and 40 gestational weeks who were scheduled for cesarean section were included in this multicenter prospective trial. Sociodemographic parameters and physical examination findings were noted and assessed as potential risk factors that may play a role in the development of low back pain.

Results: The mean age of the study population was $29.98 \pm 5.23$ years and low back pain was identified in 120 (48\%) patients. According to the logistic regression results, an increase in BMI (\%) during pregnancy (odds ratio: 1.240; $95 \% \mathrm{Cl}$ : $1.061-1.448 ; p=0.007$ ) is correlated with the presence of low back pain. Separately, receiver operating characteristic curve analysis suggested that an increase in BMI (\%) during pregnancy has a sensitivity of $77.5 \%$ and a specificity of $60 \%$ for the prediction of low back pain, and the cutoff point was found to be $15.5 \%$.

Conclusions: Our results imply that an increase in BMI (\%) was correlated with low back pain during pregnancy. Weight gain should be personalized for each pregnancy and the increase in BMI (\%) during gestation should be reduced. Measures should be taken to assure appropriate weight control to prevent low back pain during pregnancy.
\end{abstract}

Key words: pregnancy, low back pain, body weight, body mass index

Ginekologia Polska 2021; 92, 10: 714-719

\section{INTRODUCTION}

Low back pain during pregnancy has remained an incomplete puzzle in maternal medicine for some time. Pregnancy is one of the most sensitive periods during which women will suffer from low back pain in their life, with low back pain being approximately four times more common in pregnant women than those who are not at the same age [1]. Globally, 45-50\% of pregnant women may suffer from low back pain during gestation [2, 3]. Given this high rate, this clinical entity constitutes a significant health problem that remarkably deteriorates the quality of life of women and restricts their capacity to perform a job or to carry out their normal daily activities [4]. In one study, more than $80 \%$ of pregnant women with low back pain reported having difficulties with standing and walking and $68 \%$ of pregnant women with low back pain experienced pain during sexual intercourse [4]. However, since low back pain is perceived as a temporary and mild condition by the patients and their health care providers initially, it is often ignored rather than considered to be a significant disorder. On the other hand, it may be treated simply and effectively following early diagnosis with the awareness of risk factors.

Many studies hoping to understand risk factors for low back pain during and after pregnancy have been carried out to date, especially in recent years. However, the etiologic risk factors remain unclear. Low back pain in previous pregnancies is the most well-documented risk factor for such during subsequent pregnancies; however, the exact findings conflict among different studies and are simply seen as suggesting that low back pain in previous pregnancies

Corresponding author:

Serap Firtına Tuncer

Department of Obstetrics and Gynaecology, University of Health Sciences Antalya Training and Research Hospital, Antalya Eğitim ve Araştırma Hastanesi,

Varlık Mh. Kazım Karabekir Cd., 07100 Antalya, Turkey

e-mail: drserap.firtina@hotmail.com 
pairs with low back pain in the current pregnancy without a causative relationship and known pain mechanism [2, 3, $5,6]$. Maternal age, maternal weight, ethnicity, the number of previous pregnancies, and any prior abortions are some reported etiologic factors but, again, the results all conflict to some extent in previous studies $[2,3,7,8]$. In one recent study, it was also postulated that the presence and severity of low back pain were correlated with the presence and severity of striae gravidarum in pregnant women [9].

Many authors have claimed that the main mechanisms in the development of low back pain during pregnancy are related to the profound effect of pregnancy on the musculoskeletal system, which involves shifting the center of gravidity, leading to lumbar spine hyperlordosis and anterior tilting of the pelvis $[2,10]$. Some authors believe that the mechanical changes that may lead to low back pain during pregnancy are thought to be changes in body mass index (BMI) $[2,10]$. However, studies on the effects of weight gain and considering changes in BMI during pregnancy are limited in number. Moreover, the existing studies are not comprehensive and do not consider the impacts of the wide range of reported or suspected mechanical risk factors on the lumbar spine and muscles, such as intraperitoneal adhesions that may form after prior surgeries. As low back pain during pregnancy is often a health problem disabling pregnant women in daily life, the risk factors for lumbar pain during pregnancy constitute an important research priority. Thus, to add to the current body of literature, in the present study, we sought to investigate various epidemiologic and clinical risk factors including weight changes, the presence of striae gravidarum, and intraperitoneal adhesions.

\section{MATERIAL AND METHODS}

This randomized, multicenter prospective trial was implemented in the obstetrics and gynecology departments of two tertiary care centers between the University Of Health Sciences Antalya Training and Research Hospital and the Akdeniz University School of Medicine Hospital. Approval from the local institutional review board was obtained before the study (26.06.2019/597). The study was conducted in compliance with the principles of the Helsinki Declaration.

We recruited a total of 250 term pregnant women who were not in active labor and who were admitted for elective cesarean section. Pregnant women over 37 weeks of gestation were accepted as being term. As intraperitoneal adhesions could only be evaluated during cesarean section, only pregnant women who were scheduled for this procedure were included in the present study. These pregnant women were evaluated in terms of low back pain, striae gravidarum, and the presence of intraperitoneal adhesions. Sociodemographic parameters and physical examination findings were noted and assessed as possible risk factors that might play a role in the development of low back pain.

Low back pain was defined per the consensus approach regarding the standardization of back pain definitions for use in prevalence studies [11]. According to this system, pregnant women were questioned regarding the presence of back pain in the preceding four weeks and whether the pain had interfered with their performance of daily activities or altered their course of life for at least one day. Pregnant women with positive replies to both questions were accepted as positive for low back pain [11]. Data were collected using patient evaluation sheets.

The Davey scoring system was employed to classify the striae gravidarum [12]. The abdomen was divided into four quadrants, using the midline and a line drawn horizontally through the umbilicus as reference points. Each quadrant was assigned a score, with clear skin awarded zero points, moderate (1-3) striae awarded one point, and many $(\geq 4)$ striae awarded two points. The sum of the scores of all four quadrants was calculated to obtain the total striae score for each participant [12].

Exclusion criteria included the presence of systemic diseases, urgent delivery, detection of uterine contractions at initial admission, premature rupture of membranes, cervical dilatation, chronic hypertension, and failure to communicate.

\section{Statistical analysis}

Continuous variables were described by means and standard deviations or medians and quantiles and categorical variables were described by frequencies and percentages. The distribution of continuous variables was examined by using visual (e.g., histograms and probability plots) and analytical (Kolmogorov-Smirnov and Shapiro-Wilk tests) methods. The relationships between continuous variables and back pain were compared using an independent-samples t-test or the Mann-Whitney $U$ test according to the distribution of the variables. The relationship between categorical variables was compared with the chi-squared test. Independent variables with $p$-values of less than 0.05 in the univariate analysis were included in the logistic regression analysis. Also, cutoff values were determined during receiver operating characteristic curve analysis by using Youden's index. A p-value of less than 0.05 was defined as statistically significant.

\section{RESULTS}

Table 1 presents an overview of the demographic and clinical characteristics of our study population. The mean age of the study population was $29.98 \pm 5.23$ years and low back pain was identified in 120 (48\%) patients. The median numbers of gravidity and parity were three and one, 
Table 1. Demographic and clinical characteristics of the study population

\begin{tabular}{|c|c|c|}
\hline Characteristics & Parameters & Values \\
\hline Age (years) & Mean \pm Sd & $29.98 \pm 5.23$ \\
\hline Gravidity & $\begin{array}{l}\text { Median } \\
25^{5^{\text {th}}}-75^{\text {th }} \text { percentiles }\end{array}$ & $\begin{array}{c}3 \\
2-3.25\end{array}$ \\
\hline Parity & $\begin{array}{l}\text { Median } \\
25^{5^{\text {th}}}-75^{\text {th }} \text { percentiles }\end{array}$ & $\begin{array}{c}1 \\
1-2\end{array}$ \\
\hline $\begin{array}{l}\text { Gestational period } \\
\text { (days) }\end{array}$ & $\begin{array}{l}\text { Median } \\
25^{\text {th }}-75^{\text {th }} \text { percentiles }\end{array}$ & $\begin{array}{c}271 \\
266-273\end{array}$ \\
\hline \multirow{2}{*}{$\begin{array}{l}\text { Previous history of } \\
\text { surgery }\end{array}$} & $\begin{array}{l}\text { Absent } \\
\text { Present }\end{array}$ & $\begin{array}{c}46(18.4) \\
204(91.6)\end{array}$ \\
\hline & $\begin{array}{l}1 \\
2 \\
3\end{array}$ & $\begin{array}{c}138(55.2) \\
45(18.0) \\
21(8.4)\end{array}$ \\
\hline Fetal Gender & $\begin{array}{l}\text { Female } \\
\text { Male }\end{array}$ & $\begin{array}{l}129(51.6) \\
121(48.4)\end{array}$ \\
\hline Height (cm) & $\begin{array}{l}\text { Median } \\
25^{\text {th }}-75^{\text {th }} \text { percentiles }\end{array}$ & $\begin{array}{c}163 \\
159-167\end{array}$ \\
\hline $\begin{array}{l}\text { Prepregnancy body } \\
\text { weight }\end{array}$ & $\begin{array}{l}\text { Median } \\
25^{\text {th }}-75^{\text {th }} \text { percentiles }\end{array}$ & $\begin{array}{c}62 \\
56-73.25\end{array}$ \\
\hline Prepregnancy BMI & $\begin{array}{l}\text { Median } \\
25^{\text {th }}-75^{\text {th }} \text { percentiles }\end{array}$ & $\begin{array}{c}23.24 \\
21.48-28.42\end{array}$ \\
\hline $\begin{array}{l}\text { Body weight at labor } \\
(\mathrm{kg})\end{array}$ & $\begin{array}{l}\text { Median } \\
25^{5^{\text {th}}}-75^{\text {th }} \text { percentiles }\end{array}$ & $\begin{array}{c}74.5 \\
69-85\end{array}$ \\
\hline BMI at labor $\left(\mathrm{kg} / \mathrm{m}^{2}\right)$ & $\begin{array}{l}\text { Median } \\
25^{t^{\text {th }}-75^{\text {th }}} \text { percentiles }\end{array}$ & $\begin{array}{c}28.38 \\
25.46-33.28\end{array}$ \\
\hline $\begin{array}{l}\text { Weight gain during } \\
\text { pregnancy }(\mathrm{kg})\end{array}$ & $\begin{array}{l}\text { Median } \\
25^{t^{\text {th}}}-75^{\text {th }} \text { percentiles }\end{array}$ & $\begin{array}{c}12 \\
8-15\end{array}$ \\
\hline $\begin{array}{l}\text { BMl increase during } \\
\text { pregnancy }\end{array}$ & $\begin{array}{l}\text { Median } \\
25^{5^{\text {th}}}-75^{\text {th }} \text { percentiles }\end{array}$ & $\begin{array}{c}4.23 \\
3.01-5.76\end{array}$ \\
\hline $\begin{array}{l}\text { BMI increase during } \\
\text { pregnancy (\%) }\end{array}$ & $\begin{array}{l}\text { Median } \\
25^{t^{\text {th}}}-75^{\text {th }} \text { percentiles }\end{array}$ & $\begin{array}{c}17 \\
12-22\end{array}$ \\
\hline $\begin{array}{l}\text { Uterine fundus height } \\
(\mathrm{cm})\end{array}$ & $\begin{array}{l}\text { Median } \\
25^{\text {th }}-75^{\text {th }} \text { percentiles }\end{array}$ & $\begin{array}{c}34 \\
33-36\end{array}$ \\
\hline Birth weight (g) & $\begin{array}{l}\text { Median } \\
25^{\text {th }}-75^{\text {th }} \text { percentiles }\end{array}$ & $\begin{array}{c}3335 \\
3110-3590\end{array}$ \\
\hline $\begin{array}{l}\text { Working status during } \\
\text { pregnancy }\end{array}$ & $\begin{array}{l}\text { Always sitting down } \\
\text { Often sitting down } \\
\text { Half time sitting down } \\
\text { Often standing up } \\
\text { Always standing up }\end{array}$ & $\begin{array}{c}17(6.8) \\
129(51.6) \\
57(22.8) \\
32(12.8) \\
15(6.0)\end{array}$ \\
\hline Diabetes & $\begin{array}{l}\text { Absent } \\
\text { Present }\end{array}$ & $\begin{array}{l}234(93.6) \\
16(16.4)\end{array}$ \\
\hline Polyhydramnios & $\begin{array}{l}\text { Absent } \\
\text { Present }\end{array}$ & $\begin{array}{c}237(94.8) \\
13(5.2)\end{array}$ \\
\hline Striae gravidarum score & $\begin{array}{l}\text { Median } \\
25^{t^{\text {th}}}-75^{\text {th }} \text { percentiles }\end{array}$ & $\begin{array}{c}3 \\
0-8\end{array}$ \\
\hline Striae gravidarum & $\begin{array}{l}\text { Absent } \\
\text { Mild } \\
\text { Severe }\end{array}$ & $\begin{array}{c}80(32.0) \\
40(16.0) \\
130(52.0)\end{array}$ \\
\hline $\begin{array}{l}\text { Intraperitoneal } \\
\text { adhesion }\end{array}$ & $\begin{array}{l}\text { Absent } \\
\text { Film } \\
\text { Severe }\end{array}$ & $\begin{array}{c}87(34.8) \\
113(45.2) \\
50(20.0)\end{array}$ \\
\hline Low back pain & $\begin{array}{l}\text { Absent } \\
\text { Present }\end{array}$ & $\begin{array}{l}130(52.0) \\
120(48.0)\end{array}$ \\
\hline
\end{tabular}

Percentages are given in parenthesis 'Values' column. BMI — body-mass index $\mathrm{kg}$ - kilogram; $\mathrm{cm}$ - centimeter; $\mathrm{g}$ - gram respectively. The median weight gain during pregnancy was $12 \mathrm{~kg}\left(25^{\text {th }}-75^{\text {th }}\right.$ percentiles: $\left.8-15 \mathrm{~kg}\right)$ and the median BMI increase during pregnancy was $4.23 \mathrm{~kg} / \mathrm{m}^{2}\left(25^{\text {th }}\right.$ $-75^{\text {th }}$ percentiles: $3.01-5.76 \mathrm{~kg} / \mathrm{m}^{2}$ ). The median increase in the percentage (\%) of BMI from prepregnancy to labor was $17 \%$ ( $25^{\text {th }}-75^{\text {th }}$ percentiles: $\left.12-22\right)$. Striae gravidarum was detected in 170 (68.0\%) and intraperitoneal adhesions were observed in 163 (65.2\%) of participants, respectively.

The results of the analysis of the relationships between the presence of low back pain and demographic and clinical features are shown in Table 2. According to univariate analysis, gravidity $(p=0.011)$, previous history of surgery $(p=0.006)$, weight gain during pregnancy $(p<0.001), B M I$ at labor $(p=0.02), B M l$ increase during pregnancy $(p<0.001)$, BMI $(\%)$ increase during pregnancy $(p=0.001)$, standing up during work time $(p=0.002)$, striae gravidarum score $(p=0.014)$, and the presence of intraperitoneal adhesions ( $p=0.002$ ) were correlated with the presence of low back pain.

Separately, according to logistic regression results, BMI (\%) increase during pregnancy (odds ratio: $1.240 ; 95 \%$ confidence interval: $1.061-1.448 ; p=0.007$ ) was correlated with the presence of low back pain. Receiver operating characteristic curve analysis revealed that the BMI (\%) increase during pregnancy had a sensitivity of $77.5 \%$ and a specificity of $60 \%$ for the prediction of low back pain, while the cutoff point was $15.5 \%$.

\section{DISCUSSION}

The present study is a preliminary study of weight gain factors affecting low back pain. As part of this research, prepregnancy body weight and BMI, body weight and BMI at labor, weight gain, and BMI increase and BMI (\%) increase during the course of pregnancy were analyzed. Also, to our knowledge, this study is the first to evaluate the effect of striae gravidarum and intraperitoneal adhesions in the same cohort. Our results indicated that weight gain changes during pregnancy, the presence and intensity of striae gravidarum, and intraperitoneal adhesions are more frequent in pregnant women with low back pain. According to logistic regression analysis, our results support that BMI (\%) increase during pregnancy is significantly correlated with the presence of low back pain.

We found that each one-unit increase in BMI (\%) increases the occurrence of low back pain by $24 \%$. The associated weight gain may lead to an overload of the lumbar vertebra, pelvic girdle, and lower extremities and a shift in the center of gravity anteriorly as a result of these events. Thus, increased lordosis is a compensatory action to counteract this change in the center of gravity. However, increased lordosis causes low back pain due to the amplification of load on the pelvic girdle. Increased maternal weight, the laxity 


\begin{tabular}{|c|c|c|c|c|}
\hline \multirow{2}{*}{ Characteristics } & \multirow{2}{*}{ Parameters } & \multicolumn{2}{|c|}{ Low Back Pain } & \multirow{2}{*}{ P-value } \\
\hline & & Absent & Present & \\
\hline Age [years] & Mean \pm SD & $30.38 \pm 5.36$ & $29.55 \pm 5.07$ & 0.212 \\
\hline Gravidity & $\begin{array}{l}\text { Median } \\
\text { IQR }\end{array}$ & $\begin{array}{l}3 \\
2\end{array}$ & $\begin{array}{l}3 \\
1\end{array}$ & 0.011 \\
\hline Parity & $\begin{array}{l}\text { Median } \\
\text { IQR }\end{array}$ & $\begin{array}{l}1 \\
1\end{array}$ & $\begin{array}{l}2 \\
1\end{array}$ & 0.301 \\
\hline Gestation [day] & $\begin{array}{l}\text { Median } \\
\text { IQR }\end{array}$ & $\begin{array}{l}270 \\
5,5\end{array}$ & $\begin{array}{c}272 \\
7\end{array}$ & 0.862 \\
\hline Previous history of surgery & $\begin{array}{l}0 \\
1 \\
2 \\
3\end{array}$ & $\begin{array}{l}20(43.5) \\
66(47.8) \\
26(57.8) \\
18(85.7)\end{array}$ & $\begin{array}{c}26(56.5) \\
72(52.2) \\
19(42.2) \\
3(14.3)\end{array}$ & 0.006 \\
\hline Fetal Gender & $\begin{array}{l}\text { Female } \\
\text { Male }\end{array}$ & $\begin{array}{l}67(51.9) \\
63(52.1)\end{array}$ & $\begin{array}{l}62(48.1) \\
58(47.9)\end{array}$ & 0.984 \\
\hline Height & $\begin{array}{l}\text { Median } \\
\text { IQR }\end{array}$ & $\begin{array}{c}163 \\
7\end{array}$ & $\begin{array}{c}162 \\
9\end{array}$ & 0.518 \\
\hline Prepregnancy body weight & $\begin{array}{l}\text { Median } \\
\text { IQR }\end{array}$ & $\begin{array}{c}62,5 \\
22\end{array}$ & $\begin{array}{l}62 \\
16\end{array}$ & 0.338 \\
\hline Prepregnancy BMI & $\begin{array}{l}\text { Median } \\
\text { IQR }\end{array}$ & $\begin{array}{c}23.25 \\
8.08\end{array}$ & $\begin{array}{c}23.24 \\
6.89\end{array}$ & 0.830 \\
\hline Body weight at labor [kg] & $\begin{array}{l}\text { Median } \\
\text { IQR }\end{array}$ & $\begin{array}{l}73 \\
20\end{array}$ & $\begin{array}{l}75 \\
12\end{array}$ & 0.212 \\
\hline BMI at labor & $\begin{array}{l}\text { Median } \\
\text { IQR }\end{array}$ & $\begin{array}{c}27.23 \\
8.76\end{array}$ & $\begin{array}{c}29.26 \\
6.68\end{array}$ & 0.02 \\
\hline Weight gain during pregnancy [kg] & $\begin{array}{l}\text { Median } \\
\text { IQR }\end{array}$ & $\begin{array}{c}10 \\
6\end{array}$ & $\begin{array}{l}14 \\
6\end{array}$ & $<0.001$ \\
\hline $\mathrm{BMI}$ increase during pregnancy & $\begin{array}{l}\text { Median } \\
\text { IQR }\end{array}$ & $\begin{array}{c}3.50 \\
2.2\end{array}$ & $\begin{array}{l}5.07 \\
2.47\end{array}$ & $<0.001$ \\
\hline BMI increase during pregnancy [\%] & $\begin{array}{l}\text { Median } \\
\text { IQR }\end{array}$ & $\begin{array}{c}13 \\
9\end{array}$ & $\begin{array}{l}20 \\
11\end{array}$ & 0.001 \\
\hline Uterine fundus height [cm] & $\begin{array}{l}\text { Median } \\
\text { IQR }\end{array}$ & $\begin{array}{c}33 \\
3\end{array}$ & $\begin{array}{c}34 \\
3\end{array}$ & 0.071 \\
\hline Birth weight [g] & $\begin{array}{l}\text { Median } \\
\text { IQR }\end{array}$ & $\begin{array}{l}3370 \\
541\end{array}$ & $\begin{array}{c}3325 \\
400\end{array}$ & 0.658 \\
\hline Working position during pregnancy & $\begin{array}{l}\text { Always sitting down } \\
\text { Often sitting down } \\
\text { Half time sitting down } \\
\text { Often standing up } \\
\text { Always standing up }\end{array}$ & $\begin{array}{l}11(64.7) \\
74(57.4) \\
30(52.6) \\
12(37.5) \\
3(20.0)\end{array}$ & $\begin{array}{l}6(35.3) \\
55(42.6) \\
27(47.4) \\
20(62.5) \\
12(80.0)\end{array}$ & 0.022 \\
\hline Standing up during work time & $\begin{array}{l}\text { Less or equal than half time } \\
\text { More than half time }\end{array}$ & $\begin{array}{l}115(56.7) \\
15(31.9)\end{array}$ & $\begin{array}{l}88(43.3) \\
32(68.1)\end{array}$ & 0.002 \\
\hline Diabetes mellitus & $\begin{array}{l}\text { Absent } \\
\text { Present }\end{array}$ & $\begin{array}{l}120(51.3) \\
10(62.5)\end{array}$ & $\begin{array}{l}114(48.7) \\
6(37.5)\end{array}$ & 0.385 \\
\hline Polyhydramnios & $\begin{array}{l}\text { Absent } \\
\text { Present }\end{array}$ & $\begin{array}{l}126(53.2) \\
4(30.8)\end{array}$ & $\begin{array}{l}111(46.8) \\
9(69.2)\end{array}$ & 0.116 \\
\hline Striae gravidarum score & $\begin{array}{l}\text { Median } \\
\text { IQR }\end{array}$ & $\begin{array}{l}2 \\
7\end{array}$ & $\begin{array}{l}4 \\
7\end{array}$ & 0.014 \\
\hline Striae gravidarum & $\begin{array}{l}\text { Absent } \\
\text { Mild } \\
\text { Severe }\end{array}$ & $\begin{array}{l}53(66.3) \\
15(37.5) \\
62(47.7)\end{array}$ & $\begin{array}{l}27(33.8) \\
25(62.5) \\
68(52.3)\end{array}$ & 0.004 \\
\hline & $\begin{array}{l}\text { Absent } \\
\text { Mild/Severe }\end{array}$ & $\begin{array}{l}53(66.3) \\
77(45.3)\end{array}$ & $\begin{array}{l}27(33.8) \\
93(54.7)\end{array}$ & 0.002 \\
\hline Intraperitoneal adhesion & $\begin{array}{l}\text { Absent } \\
\text { Film } \\
\text { Severe }\end{array}$ & $\begin{array}{l}49(56.3) \\
65(57.5) \\
16(32.0)\end{array}$ & $\begin{array}{l}38(43.7) \\
48(42.5) \\
34(68.0)\end{array}$ & 0.007 \\
\hline & $\begin{array}{l}\text { Absent } \\
\text { Film/Severe }\end{array}$ & $\begin{array}{c}114(57) \\
16(32)\end{array}$ & $\begin{array}{l}86(43) \\
34(68)\end{array}$ & 0.002 \\
\hline
\end{tabular}

Percentages are given in parenthesis in 'Low Back Pain' column. BMI — body-mass index; kg — kilogram; cm — centimeter; $\mathrm{g}$ - gram; IQR — interquartile range 
of ligaments that stabilize the vertebral and sacroiliac ligaments, direct compression of lumbosacral nerve roots by the uterus and fetus, the tension of spinal antigravity muscles due to an insufficiency of anterior abdominal muscles, and muscular fatigue may lead to low back pain $[13,14]$. The increase in BMI may be reflected as a remarkably increased mechanical load on the pelvic and lumbar joints leading to increased low back pain. Thus, the pain usually starts in the $18^{\text {th }}$ week of gestation and attains peak intensity between the $24^{\text {th }}$ and $36^{\text {th }}$ weeks [7]. This shows the effect of weight gain and compensatory mechanisms on low back pain during the progress of pregnancy through the trimesters. Even though low back pain during pregnancy disappears in 93\% of cases within three months, $7 \%$ of patients experience persistent and severe pain after delivery [7]. Excessive weight gain during pregnancy is also correlated with low back pain after pregnancy [15]). It was reported that pregnant women with a gestational weight gain of $15 \mathrm{~kg}$ or more are 2.3 times more likely to experience low back pain relative to women with less than $10 \mathrm{~kg}$ of gestational weight gain [15]. This situation alongside our findings leads us to stress the importance of reducing the weight back to prepregnancy levels after delivery to decrease lumbosacral pain.

The Institute of Medicine recommends a total weight gain not exceed 12.5 to $18 \mathrm{~kg}$ for underweight women, 11.5 to $16 \mathrm{~kg}$ for normal-weight women, 7 to $11.5 \mathrm{~kg}$ for overweight women, and 5 to $9 \mathrm{~kg}$ for obese women during pregnancy [16]. These recommendations aim to prevent adverse maternal and fetal health conditions. Such that inadequate gestational weight gain was asoociated with small for geatational age newborns whereas excessive gestational weight gain was associated with large for gestational age newborns [17]. In the case of low back pain during pregnancy, according to our results, weight gain should not be standardized for women with the same prepregnancy body weights. The increase in BMI (\%) has more impact on the occurrence of low back pain when compared with gestational weight gain. Moreover, according to our results, to decrease the occurrence of low back pain, weight gain should be personalized for each pregnant depending on her prepregnancy body weight and height. Thus, certain weight gain (or increase in BMI) for pregnant women having lower prepregnancy BMI values is correlated with greater low back pain when compared with a similar amount of weight gain in pregnant women with higher prepregnancy BMI values. This may be explained by the weaker adaptation and because the strengthening of capacities of the musculoskeletal system to handle the body weight increase over a very short time like pregnancy may vary from woman to woman [10]. According to our results, these capacities may be lower in pregnant women with lower prepregnancy BMI values such that the same amount of body load increase more severely affects pregnant women with weaker and taller bodies. This hypothesis should be investigated in further biomechanical studies in pregnant women.

In addition, we found that a $15.5 \%$ increase in prepregnancy BMI has a sensitivity of $77.5 \%$ and specificity of $60 \%$ for the occurrence of low back pain. That means that, with a $15.5 \%$ increase in prepregnancy BMI, the probability of low back pain in a woman is $77.5 \%$. However, if there is no increase in BMI of $15.5 \%$ or greater, the probability of the absence of low back pain is just $60 \%$. Our results suggest the presence of other etiologic factors like exercises during pregnancy probably interfere with body weight and compensatory musculoskeletal etiopathogenesis. As compensatory mechanisms demonstrated by the musculoskeletal system play a role in the development of low back pain, muscle-strengthening exercises should not be neglected during pregnancy. Thus, pregnant women should be encouraged to engage in regular exercise as it was shown that regular exercise adherence is associated with positive long-term effects on BMI [18].

The results of our study may not fit with all pregnant women globally of different ethnicities because genetics, working status and nutrition habits may change geographically, however, our study is unique in terms of analyzing various epidemiologic and clinical risk factors including weight changes, the presence of striae gravidarum, and intraperitoneal adhesions in pregnant women for low back pain.

\section{CONCLUSIONS}

To conclude, low back pain during pregnancy is a common disorder, but its etiopathogenesis is not well-understood at this time. Our results imply that an increase in BMI (\%) is correlated with low back pain during pregnancy. Weight gain should be personalized for each pregnancy depending on the BMI. The increase in BMI (\%) should be minimalized. Finally, weight control should be achieved with a multidisciplinary approach that includes proper nutrition and exercise to prevent low back pain during pregnancy.

\section{Acknowledgements}

We would like to thank all the healthcare professionals who participated in the cesarean delivery of pregnant women.

\section{Conflict of interests}

No potential conflict of interest was reported by the authors.

\section{REFERENCES}

1. Biering-Sorensen F. Low back trouble in a general population of 30-, 40-, 50-, and 60-year-old men and women. Study design, representativeness and basic results. Dan Med Bull. 1982; 29(6): 289-299.

2. Majchrzycki M, Mrozikiewicz PM, Kocur P, et al. Low back pain in pregnant women. Ginekol Pol. 2010; 81(11): 851-855, indexed in Pubmed: 21365902. 
3. Wu WH, Meijer OG, Uegaki K, et al. Pregnancy-related pelvic girdle pain (PPP), I: Terminology, clinical presentation, and prevalence. Eur Spine J. 2004; 13(7): 575-589, doi: 10.1007/s00586-003-0615-y, indexed in Pubmed: 15338362.

4. Mens JM, Vleeming A, Stoeckart R, et al. Understanding peripartum pelvic pain. Implications of a patient survey. Spine (Phila Pa 1976). 1996; 21(11): 1363-9; discussion 1369, doi: 10.1097/00007632-19960601000017, indexed in Pubmed: 8725930.

5. Sencan S, Ozcan-Eksi EE, Cuce I, et al. Pregnancy-related low back pain in women in Turkey: Prevalence and risk factors. Ann Phys Rehabil Med. 2018; 61(1): 33-37, doi: 10.1016/j.rehab.2017.09.005, indexed in Pubmed: 29042300.

6. Wang SM, Dezinno P, Maranets I, et al. Low back pain during pregnancy: prevalence, risk factors, and outcomes. Obstet Gynecol. 2004; 104(1): 65-70, doi: 10.1097/01.AOG.0000129403.54061.0e, indexed in Pubmed: 15229002.

7. Ostgaard HC, Andersson GB, Wennergren M. The impact of low back and pelvic pain in pregnancy on the pregnancy outcome. Acta Obstet Gynecol Scand. 1991; 70(1): 21-24, doi: 10.3109/00016349109006172, indexed in Pubmed: 1830444.

8. Mogren IM, Pohjanen Al. Low back pain and pelvic pain during pregnancy: prevalence and risk factors. Spine (Phila Pa 1976). 2005; 30(8): 983-991, doi: 10.1097/01.brs.0000158957.42198.8e, indexed in Pubmed: 15834344.

9. Kokanalı D, Çağlar AT. Hidden association between the presence and severity of striae gravidarum and low back pain in pregnancy. Eur J Obstet Gynecol Reprod Biol. 2019; 233: 49-52, doi: 10.1016/j. ejogrb.2018.12.004, indexed in Pubmed: 30562618.

10. Casagrande D, Gugala Z, Clark SM, et al. Low back pain and pelvic girdle pain in pregnancy. J Am Acad Orthop Surg. 2015; 23(9): 539-549, doi: 10.5435/JAAOS-D-14-00248, indexed in Pubmed: 26271756.
11. Dionne CE, Dunn KM, Croft PR, et al. A consensus approach toward the standardization of back pain definitions for use in prevalence studies. Spine (Phila Pa 1976). 2008; 33(1): 95-103, doi: 10.1097/BRS.0b013e31815e7f94, indexed in Pubmed: 18165754.

12. Davey CM. Factors associated with the occurrence of striae gravidarum. J Obstet Gynaecol Br Commonw. 1972; 79(12): 1113-1114, doi: 10.1111/ j.1471-0528.1972.tb11896.x, indexed in Pubmed: 4646568.

13. Carlson HL, Carlson NL, Pasternak BA, et al. Understanding and managing the back pain of pregnancy. Curr Womens Health Rep. 2003; 3(1):65-71, indexed in Pubmed: 12521555.

14. To WWK, Wong MWN. Factors associated with back pain symptoms in pregnancy and the persistence of pain 2 years after pregnancy. Acta Obstet Gynecol Scand. 2003; 82(12): 1086-1091, doi: 10.1046/j.1600-0 412.2003.00235.x, indexed in Pubmed: 14616251.

15. Matsuda N, Kitagaki K, Perrein E, et al. Association between excessive weight gain during pregnancy and persistent low back and pelvic pain after delivery. Spine (Phila Pa 1976). 2020; 45(5): 319-324, doi: 10.1097/BRS.0000000000003271, indexed in Pubmed: 31593058.

16. Rassmussen KM, Yaktine AL. Institute of Medicine (US) and National Research Council (US) Committee to Reexamine IOM Pregnancy Weight Guidelines. Weight gain during pregnancy: reexamining the guidelines. The National Academies Collection: Reports funded by National Institutes of Health, Washington (DC) 2009.

17. Nowak M, Kalwa M, Oleksy $P$, et al. The relationship between pre-pregnancy $\mathrm{BMI}$, gestational weight gain and neonatal birth weight: a retrospective cohort study. Ginekol Pol. 2019; 90(1): 50-54, doi: 10.5603/GP.2019.0008, indexed in Pubmed: 30756371.

18. Shiri R, Coggon D, Falah-Hassani K. Exercise for the prevention of low back and pelvic girdle pain in pregnancy: A meta-analysis of randomized controlled trials. Eur J Pain. 2018; 22(1): 19-27, doi: 10.1002/ejp.1096, indexed in Pubmed: 28869318. 